\title{
Calcium Signaling in Dendritic Spines
}

\author{
Michael J. Higley ${ }^{1}$ and Bernardo L. Sabatini ${ }^{2}$ \\ ${ }^{1}$ Department of Neurobiology, Program in Cellular Neuroscience, Neurodegeneration and Repair, \\ Yale School of Medicine, New Haven, Connecticut 06520 \\ ${ }^{2}$ Howard Hughes Medical Institute, Department of Neurobiology, Harvard Medical School, Boston, \\ Massachusetts 02115 \\ Correspondence: bsabatini@hms.harvard.edu
}

Calcium $\left(\mathrm{Ca}^{2+}\right)$ is a ubiquitous signaling molecule that accumulates in the cytoplasm in response to diverse classes of stimuli and, in turn, regulates many aspects of cell function. In neurons, $\mathrm{Ca}^{2+}$ influx in response to action potentials or synaptic stimulation triggers neurotransmitter release, modulates ion channels, induces synaptic plasticity, and activates transcription. In this article, we discuss the factors that regulate $\mathrm{Ca}^{2+}$ signaling in mammalian neurons with a particular focus on $\mathrm{Ca}^{2+}$ signaling within dendritic spines. This includes consideration of the routes of entry and exit of $\mathrm{Ca}^{2+}$, the cellular mechanisms that establish the temporal and spatial profile of $\mathrm{Ca}^{2+}$ signaling, and the biophysical criteria that determine which downstream signals are activated when $\mathrm{Ca}^{2+}$ accumulates in a spine. Furthermore, we also briefly discuss the technical advances that made possible the quantitative study of $\mathrm{Ca}^{2+}$ signaling in dendritic spines.

Eor many neurons in the mammalian brain, - the postsynaptic terminal of an excitatory synapse is found in a specialized structure protruding from the dendritic shaft, known as a dendritic spine (Fig. 1). The structure of the classic mushroom-shaped dendritic spine, in which a bulbous head (diameter $\sim 0.5 \mu \mathrm{m}$ ) is separated from the parent dendritic shaft by a thin neck (length $\sim 0.5 \mu \mathrm{m}$, diameter $\sim 0.1$ $\mu \mathrm{m})$, suggests that it creates an isolated signaling compartment in which the machinery necessary to read out and regulate the activity of one synapse can operate independently of that associated with a neighboring synapse. Indeed, many studies have shown that the spine neck provides a significant barrier to diffusion that allows compartmentalization of biochemical and electrical signals in the spine head (Yuste and Denk 1995; Svoboda et al. 1996; Sabatini et al. 2002; Grunditz et al. 2008; Bloodgood et al. 2009). The generalizability of these conclusions to non-mushroom spines (see Harris and Weinberg 2012), such as those with no discernible neck (stubby spines) or those with a long neck and small head (thin spines), is still unclear.

The best-studied, synaptically evoked biochemical signal that accumulates in active spines is intracellular calcium $\left(\mathrm{Ca}^{2+}\right.$ ) (for review, see Sabatini et al. 2001; Bloodgood and Sabatini 2007a; Higley and Sabatini 2008). In pyramidal neurons of the neocortex and hippocampus, synaptic activation of NMDA-type glutamate

Editors: Morgan Sheng, Bernardo Sabatini, and Thomas C. Südhof

Additional Perspectives on The Synapse available at www.cshperspectives.org

Copyright (C) 2012 Cold Spring Harbor Laboratory Press; all rights reserved; doi: 10.1101/cshperspect.a005686

Cite this article as Cold Spring Harb Perspect Biol 2012;4:a005686 


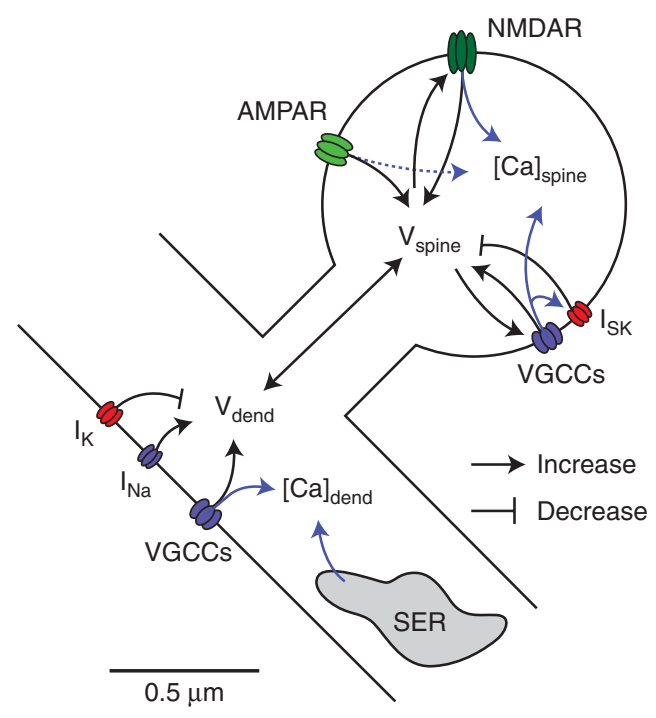

Figure 1. Sources and regulation of $\mathrm{Ca}^{2+}$ in dendritic spines. Synaptic stimulation produces postsynaptic depolarization via currents (black arrows) through AMPA- and NMDA-type glutamate receptors as well as various voltage-gated ion channels. Synaptic $\mathrm{Ca}^{2+}$ influx (blue arrows) is mediated by NMDARs and voltage-gated $\mathrm{Ca}^{2+}$ channels (VGCCs) and is possibly augmented by release from intracellular stores such as smooth endoplasmic reticulum (SER). The membrane potentials within the spine $\left(\mathrm{V}_{\text {spine }}\right)$ and dendritic shaft $\left(\mathrm{V}_{\text {dend }}\right)$ are electrically coupled by the spine neck. Similarly, the $\mathrm{Ca}^{2+}$ concentrations in the spine $\left([\mathrm{Ca}]_{\text {spine }}\right.$ and dendritic shaft $\left.[\mathrm{Ca}]_{\text {dend }}\right)$ are coupled by restricted diffusion across the neck. The presence of Ca-activated (SK) potassium channels in the spine head provides a negative-feedback loop regulating synaptic depolarization. Sodium $\left(\mathrm{I}_{\mathrm{Na}}\right)$ and potassium $\left(\mathrm{I}_{\mathrm{K}}\right)$ channels, as well as SER, are shown only in the dendritic shaft for simplicity but may also be present in the spine head. Note that for clarity the spine neck is not drawn to scale.

receptors (NMDARs) located in the postsynaptic density (PSD) leads to influx of $\mathrm{Ca}^{2+}$, which accumulates in the head of the spine associated with the active synapse (Fig. 1). Additional $\mathrm{Ca}^{2+}$ enters through voltage-gated $\mathrm{Ca}^{2+}$ channels (VGCCs) or may be released from intracellular $\mathrm{Ca}^{2+}$ stores such as mitochondria and endoplasmic reticulum. Current carried by $\mathrm{Ca}^{2+}$ ions contributes to dendritic electrical signaling, producing postsynaptic depolarization. Additionally, $\mathrm{Ca}^{2+}$ ions in the spine head acti- vate a wide variety of Ca-sensitive proteinsincluding calmodulin, $\mathrm{Ca}^{2+} /$ calmodulin-dependent kinase type II (CaMKII), small conductance $\mathrm{Ca}^{2+}$-activated potassium channels, calcineurin, and calpain - that regulate many aspects of neuron and synapse function. Thus, the $\mathrm{Ca}^{2+}$ that accumulates in the spine is a central signaling molecule that regulates many aspects of synapse and cell function.

\section{TOOLS TO STUDY $\mathrm{Ca}^{2+}$ SIGNALING IN DENDRITIC SPINES}

The explosion in our quantitative understanding of $\mathrm{Ca}^{2+}$ signaling in dendritic spines has been made possible by three fundamental technical advances that are briefly discussed here (for review, see Yasuda et al. 2004). These are the development of bright, fast, and high-dynamic-range $\mathrm{Ca}^{2+}$-sensitive fluorophores; the development and dissemination of two-photon laser-scanning microscopy; and the development of two-photon released caged neurotransmitters that allow direct stimulation of visualized spines (Tsien 1980; Minta et al. 1989; Denk et al. 1990; Matsuzaki et al. 2001; Carter and Sabatini 2004; Yasuda et al. 2004).

$\mathrm{Ca}^{2+}$ accumulation within cells and dendritic spines can be visualized through the use of $\mathrm{Ca}^{2+}$-sensitive fluorescent molecules that are commonly referred to as " $\mathrm{Ca}^{2+}$ indicators." The current generation of these molecules typically consists of a $\mathrm{Ca}^{2+}$-binding molecule, such as the common $\mathrm{Ca}^{2+}$ buffer 1,2-bis(o-aminophenoxy)ethane- $N, N, N^{\prime}, N^{\prime}$-tetraacetic acid (BAPTA), that has been attached to a fluorophore such as fluorescein (Tsien 1980; Minta et al. 1989). $\mathrm{Ca}^{2+}$ binding to the buffer moiety triggers a change in the electronic properties of the fluorophore that alters its fluorescence, typically by altering its quantum yield or absorption cross section (Kao 1994; Wokosin et al. 2004). In this case, intracellular $\mathrm{Ca}^{2+}$ accumulation alters the emission of green fluorescence, which can be detected by CCD cameras or photomultiplier tubes (Fig. 2). $\mathrm{Ca}^{2+}$ indicators are now available that differ widely in their properties. For example, although indicators most often used for the study of dendritic spines fluoresce 
A

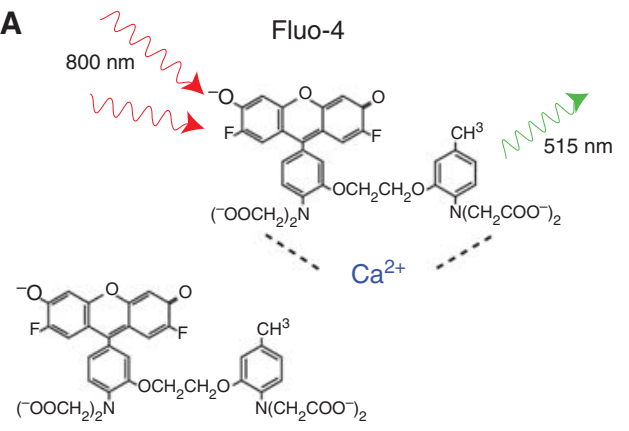

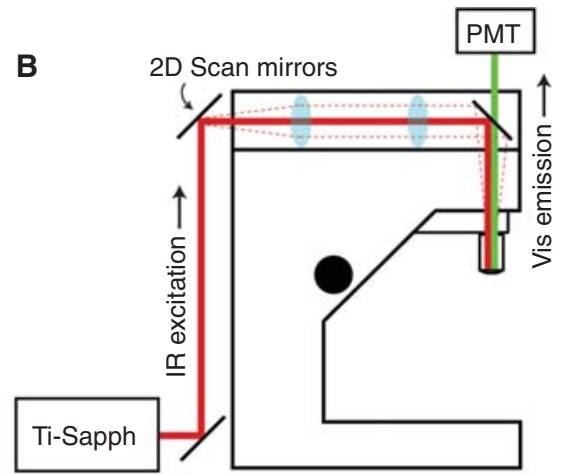

C

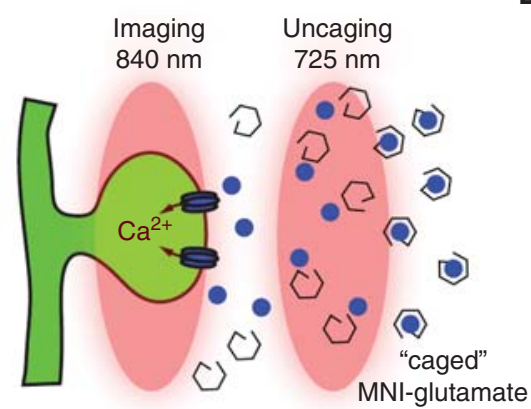

D
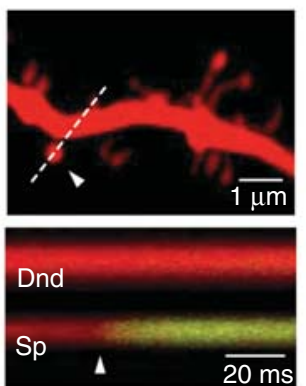

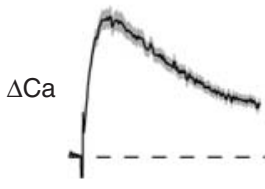

$0.5 \mathrm{mV}$

$4 \% \Delta \mathrm{G} / \mathrm{R}$

EPSP

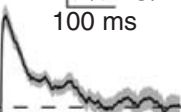

Figure 2. $\mathrm{Ca}^{2+}$-sensitive fluorophores and two-photon excitation. $(A)$ The structure of the $\mathrm{Ca}^{2+}$-sensitive fluorophore Fluo-4 is shown (lower left). This molecule consists of aromatic moiety, based on fluorescein, connected to a negatively charged $\mathrm{Ca}^{2+}$-binding molecule, based on BAPTA. When $\mathrm{Ca}^{2+}$ binds to the buffer via coordination of the negative charges (upper molecule), the quantum yield, and thus fluorescence, of Fluo- 4 increases dramatically. In the $\mathrm{Ca}^{2+}$-bound state, Fluo-4 can be excited by a single blue photon (not shown) or via nearsimultaneous absorption of two low-energy red photons (i.e., two-photon stimulation). In either case, the emission consists of a single green photon. (B) Simple schematic of a two-photon scanning microscope. Infrared $(\sim 800 \mathrm{~nm})$ light (red line) is generated by a high-energy titanium sapphire laser and directed into the microscope objective via a light path consisting of a scanning galvanometer mirror system that scans the laser in two dimensions and a telescope. The mirrors are used to scan the excitation beam through the sample. Visible fluorescence (green line) produced at the sample is collected and directed into a photomultiplier tube for image formation. (C) Schematic illustrating two-photon imaging of $\mathrm{Ca}^{2+}$ transients evoked by simultaneous twophoton glutamate uncaging. A neuron is filled with a $\mathrm{Ca}^{2+}$ indicator, such as Fluo-4, via the recording pipette and bathed in the inactive but photolabile compound MNI-glutamate. One laser $(840 \mathrm{~nm})$ is scanned across the tissue to image fluorescence. A second laser $(725 \mathrm{~nm})$ is directed next to the spine head, where a brief pulse breaks the covalent bond between glutamate and the blocking moiety. The released glutamate molecules bind synaptic NMDARs and lead to $\mathrm{Ca}^{2+}$ influx. (D) Example of uncaging-evoked synaptic $\mathrm{Ca}^{2+}$ transient in a dendritic spine. The neuron has been filled with the $\mathrm{Ca}^{2+}$-insensitive red fluorophore Alexa Fluor-594 to reveal spine morphology and the $\mathrm{Ca}^{2+}$-sensitive green fluorophore Fluo-4. Two-photon glutamate uncaging at the indicated location (arrowhead) evokes a brief $\mathrm{Ca}^{2+}$ transient $(\Delta \mathrm{Ca})$ and corresponding excitatory postsynaptic potential (EPSP).

green light (e.g., Fura-2, Oregon Green-BAPTA, Fluo-4), some indicators emit blue or red light (e.g., X-Rhod). In addition, the affinities of available indicators for $\mathrm{Ca}^{2+}$ vary over several orders of magnitude, from $\sim 10^{-7}$ to $10^{-3} \mathrm{M}$. Last, although the ease of use, fast $\mathrm{Ca}^{2+}$ binding, and brightness of synthetic $\mathrm{Ca}^{2+}$ indicators have made them the gold standard, the progress in developing genetically encoded $\mathrm{Ca}^{2+}$ indicators may soon yield designer proteins suitable for the study of synaptic $\mathrm{Ca}^{2+}$ signaling (Miyawaki et al. 1997; Nagai et al. 2001; Mank et al. 
2006; Tian et al. 2009). By careful consideration of the properties of the $\mathrm{Ca}^{2+}$ transient under study, it is typically possible to choose a $\mathrm{Ca}^{2+}$ indicator and the concentration at which it is used such that the magnitude of fluorescence change is directly and nearly linearly related to the change in intracellular $\mathrm{Ca}^{2+}$ concentration.

However, despite the relative ease of use of $\mathrm{Ca}^{2+}$ indicators, great care must be taken in the analysis of $\mathrm{Ca}^{2+}$-dependent changes in the fluorescence emitted by a $\mathrm{Ca}^{2+}$ indicator. Because $\mathrm{Ca}^{2+}$ indicators bind $\mathrm{Ca}^{2+}$ and are often present at high concentrations, from a biochemical signaling point of view, they are functionally equivalent to a $\mathrm{Ca}^{2+}$ buffer such as BATPA or EGTA. Hence, their presence fundamentally perturbs the $\mathrm{Ca}^{2+}$ transient to be analyzed, typically greatly reducing its amplitude, increasing its duration, and accelerating its spatial spread (Box 1). Furthermore, the blunting effect they have on the amplitude of evoked $\mathrm{Ca}^{2+}$ transients typically prevents or dampens the activation of downstream $\mathrm{Ca}^{2+}$-dependent processes. Thus, it is generally difficult to study both a $\mathrm{Ca}^{2+}$-dependent process and the triggering $\mathrm{Ca}^{2+}$ transient at the same time. Several studies have discussed quantitative descriptions of the perturbing properties of $\mathrm{Ca}^{2+}$ buffers and practical considerations in selecting a $\mathrm{Ca}^{2+}$ indicator (Neher and Augustine 1992; Tank et al. 1995; Neher 1998; Sabatini et al. 2001; Yasuda et al. 2004; Higley and Sabatini 2008).

A second complication that arises in the study of synaptic $\mathrm{Ca}^{2+}$ signaling is that dendritic spines are small (Harris and Stevens 1988, 1989; Südhof and Rizo 2011) Thus, many features, including the spine neck and PSD, cannot be accurately imaged with visible light-based microscopy. In addition, mammalian brain tissue is highly scattering and absorbent to visible photons, rendering the direct visualization of dendritic spines difficult. For this reason, much of the recent study of $\mathrm{Ca}^{2+}$ signaling in dendritic spines has taken advantage of two-photon laserscanning fluorescence microscopy. This approach uses the nonlinear near-infrared lightbased excitation of fluorophores to allow imaging of dendritic spines deep within brain tissue

\section{BOX 1. $\mathrm{Ca}^{2+}$ BUFFERING BY ENDOGENOUS AND EXOGENOUS MOLECULES}

Intracellular calcium (Ca) reversibly binds to endogenous molecules such as the $\mathrm{Ca}^{2+}$-binding proteins calbindin, parvalbumin, and calmodulin. In addition, $\mathrm{Ca}^{2+}$ binds to experimentally introduced molecules including buffers such as EGTA and BAPTA, synthetic $\mathrm{Ca}^{2+}$ indicators such as Fura-2 and Fluo-4, and the genetically encoded $\mathrm{Ca}^{2+}$ indicators GCAMP and TN-XL. Although exogenously applied $\mathrm{Ca}^{2+}$ buffers have been used extensively as tools to study $\mathrm{Ca}^{2+}$ function, particularly when used as fluorescent indicators of intracellular $\mathrm{Ca}^{2+}$ concentration, all buffers (both endogenous and exogenous) alter the dynamics of $\mathrm{Ca}^{2+}$ signaling. Understanding the nature of this perturbation is critical to the proper interpretation of data derived with these tools.

The effects of buffering on the dynamics of intracellular $\mathrm{Ca}^{2+}$ concentration have been quantitatively described (Neher and Augustine 1992; Zhou and Neher 1993). The equilibrium between free $\mathrm{Ca}^{2+}$, molecules of unbound buffer (B), and $\mathrm{Ca}^{2+}$-bound buffer $(\mathrm{BCa})$ is described by the laws of mass action as:

$$
[\mathrm{Ca}]+[\mathrm{B}] \leftrightarrow[\mathrm{BCa}]
$$

with equilibrium dissociation constant:

$$
K_{D}=\frac{[\mathrm{Ca}][\mathrm{B}]}{[\mathrm{BCa}]}
$$

The specific relationship between a change in the concentration of free $\mathrm{Ca}^{2+}$ concentration and the corresponding change in the concentration of $\mathrm{Ca}^{2+}$-bound buffer is described quantitatively by

Continued 


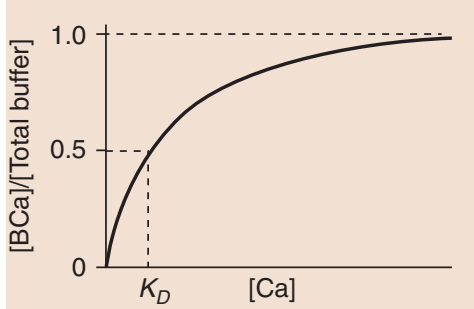

the buffer capacity, $\kappa_{B}$, defined as the incremental change in $\mathrm{BCa}^{2+}$ for an incremental change in free $\mathrm{Ca}^{2+}$ :

$$
\kappa_{B}=\frac{\delta[\mathrm{BCa}]}{\delta[\mathrm{Ca}]}
$$

This relationship defines the slope of the familiar saturating curve relating the concentrations of free $\mathrm{Ca}^{2+}$ and $\mathrm{Ca}^{2+}$-bound buffer (Fig. 3). The nonlinearity of the curve indicates that $\kappa_{B}$ is not constant but decreases as $\mathrm{Ca}^{2+}$ increases. Intuitively, at higher $\mathrm{Ca}^{2+}$ concentrations, a greater fraction of the total buffer is bound, and less is available to sequester further increases in $\mathrm{Ca}^{2+}$. The buffer capacity $\kappa_{B}$ is directly proportional to $\mathrm{Ca}^{2+}$ affinity (or inversely proportional to $K_{D}$ ) and the concentration of the buffer. Thus, high-affinity buffers strongly sequester free $\mathrm{Ca}^{2+}$, but are also saturated more readily (Higley and Sabatini 2008).

In response to a brief increase in total cytosolic $\mathrm{Ca}^{2+}$ (such as occurs during a synaptic event or action potential), the presence of exogenous buffer produces several perturbations in the dynamics of free $\mathrm{Ca}^{2+}$ concentration compared with what would occur in the absence of added buffers. The degree of perturbation is directly proportional to the fractional buffer capacity that comes from exogenous buffers.

First, the added buffer temporarily sequesters $\mathrm{Ca}^{2+}$ ions, preventing their interaction with other intracellular molecules. Quantitatively, the change in free $\mathrm{Ca}^{2+}$ is equal to the change in total $\mathrm{Ca}^{2+}$ scaled by the sum of the capacities of each buffer in the cell. Or, considering simply one exogenous buffer with capacity $\kappa_{E}$ and total native buffer capacity $\kappa_{N}$ :

$$
\Delta[\mathrm{Ca}]=\frac{\Delta \mathrm{Ca}_{T}}{1+\kappa_{E}+\kappa_{N}}
$$

Thus, relative to the situation without added buffers (i.e., $\kappa_{E}=0$ ), the amplitudes of evoked $\mathrm{Ca}^{2+}$ transients are reduced in proportion to the relative increases in buffer capacity. Because $100 \mu \mathrm{M}$ of EGTA or BAPTA provides a buffer capacity of $\sim 250$ and spines have native buffer capacities of $\sim 20$ (Sabatini et al. 2002), the exogenous buffers can very quickly dominate and reduce the amplitude of free $\mathrm{Ca}^{2+}$ transients by more than a factor of 10 . The functional consequences of this reduction are well known to investigators of $\mathrm{Ca}^{2+}$-dependent long-term synaptic plasticity, as the experimental introduction of EGTA or BAPTA can reduce or prevent plasticity induction as well as many other $\mathrm{Ca}^{2+}$-dependent processes.

Second, somewhat counter-intuitively, the presence of buffer prolongs the time that $\mathrm{Ca}^{2+}$ is present in the cytosol by slowing the time course of $\mathrm{Ca}^{2+}$ clearance. Free $\mathrm{Ca}^{2+}$ is primarily cleared by extrusion through the cell membrane or by pumping into intracellular storage sites such as mitochondria and endoplasmic reticulum. By preventing $\mathrm{Ca}^{2+}$ ions from binding to pumps, buffers increase the total time necessary to remove $\mathrm{Ca}^{2+}$ from the cytosol. Quantitatively, the time constant $(\tau)$ of the exponential time course of decay of free $\mathrm{Ca}^{2+}$ is inversely proportional

Continued 
M.J. Higley and B.L. Sabatini

to the rate of clearance $(\gamma)$ and directly proportional to the total buffer capacity:

$$
\tau=\frac{1+\kappa_{E}+\kappa_{N}}{\gamma}
$$

Thus, the fractional slowing of $\mathrm{Ca}^{2+}$ clearance is proportional to the relative change in buffer capacity caused by the addition of an exogenous buffer. Furthermore, cells with higher native buffer capacity will, given a fixed membrane concentration of $\mathrm{Ca}^{2+}$ pumps, clear $\mathrm{Ca}^{2+}$ more slowly.

Third, the presence of buffer expands the spatial extent of $\mathrm{Ca}^{2+}$ signaling in the cytosol. Intracellular $\mathrm{Ca}^{2+}$ signaling is spatially limited because the spread of $\mathrm{Ca}^{2+}$ ions is limited by binding to endogenous large $\mathrm{Ca}^{2+}$-binding proteins (Soler-Llavina and Sabatini 2006; Schmidt et al. 2007). In contrast, exogenous $\mathrm{Ca}^{2+}$ buffers are typically small ( $\left.\sim 500 \mathrm{Da}\right)$, charged molecules and are highly mobile in the intracellular space. Thus, $\mathrm{Ca}^{2+}$ "catches a ride" while bound on the mobile buffer, bypassing the $\mathrm{Ca}^{2+}$-binding proteins and ultimately unbinding at a more distal location. Quantitatively, the effective diffusion coefficient for $\mathrm{Ca}^{2+}\left(D_{\text {eff }}\right)$ in the presence of buffers is the average of the diffusion coefficients of free and buffer-bound $\mathrm{Ca}^{2+}$, weighted by the buffer capacities:

$$
D_{\text {eff }}=\frac{D_{\mathrm{Ca}}+D_{E} \kappa_{E}+D_{N} \kappa_{N}}{1+\kappa_{E}+\kappa_{N}}
$$

Here, $D_{\mathrm{Ca}}, D_{E}$, and $D_{N}$ are the diffusion coefficients of free $\mathrm{Ca}^{2+}$, endogenous, and native buffers in the cytoplasm. Thus, the presence of added buffer may break down normal diffusional barriers in small cellular compartments that are critical for physiological $\mathrm{Ca}^{2+}$ signaling.

In summary, in response to a brief rise in intracellular $\mathrm{Ca}^{2+}$ following synaptic activity or a backpropagating action potential, the presence of $\mathrm{Ca}^{2+}$ buffers reduces the magnitude of the increase in free $\mathrm{Ca}^{2+}$, prolongs the kinetics of decay of the $\mathrm{Ca}^{2+}$ transient, and increases the diffusional spread of $\mathrm{Ca}^{2+}$.

(Denk et al. 1990; Denk and Svoboda 1997). However, it does so at the cost of reduced imaging resolution (owing to the longer wavelengths used), further obscuring many features of dendritic spines (however, for a practical consideration of this point, see Cox and Sheppard 2004). Importantly, the advent of laser-scanning supraresolution microscopy, in which imaging resolution is better than the limit imposed by the diffraction of light, may soon overcome this challenge.

Last, the study of synaptic $\mathrm{Ca}^{2+}$ signaling in dendritic spines is made difficult by the complexity of the mammalian brain. The high packing density of synapses and the dense intercrossing of axons within the neuropil make it difficult to stimulate a single synapse in isolation. It is even more challenging to visualize a dendritic spine while selectively stimulating the apposed presynaptic axon (although, see Yuste and Denk 1995; Emptage et al. 1999; Oertner et al. 2002). Thus, the study of postsynaptic sig- naling in dendritic spines was greatly helped by the development of photosensitive derivatives of neurotransmitters that are inert in their parent form but release a fully functional neurotransmitter following exposure to light of the appropriate wavelength. The best characterized of these is MNI-glutamate, which can be readily photolyzed via two-photon excitation to selectively activate glutamate receptors on individual visualized spines within complex brain tissue (Canepari et al. 2001; Matsuzaki et al. 2001). This approach has been coupled with twophoton fluorescence imaging to allow the direct probing of synaptic $\mathrm{Ca}^{2+}$ signaling in an individual dendritic spine without the need to electrically activate axons.

\section{MECHANISMS OF $\mathrm{Ca}^{2+}$ ENTRY}

Synaptically coupled $\mathrm{Ca}^{2+}$ signals within dendritic spines originate from several sources that vary in the magnitude of $\mathrm{Ca}^{2+}$ transient 
produced, the time course of $\mathrm{Ca}^{2+}$ rise and decay, and the coupling to downstream biochemical pathways. Here, we consider the three most well-characterized sources of synaptic $\mathrm{Ca}^{2+}$ : ionotropic glutamate receptors, voltage-gated calcium channels, and internal calcium stores.

\section{Glutamate Receptors}

Ionotropic glutamate receptors comprise a heterogeneous group of ligand-gated ion channels, which bind the amino acid glutamate and are permeable to monovalent (and, in some cases, divalent) cations. They show reversal potentials near $0 \mathrm{mV}$ and mediate the vast majority of excitatory synaptic transmission in the nervous system. Glutamate receptors were initially grouped by their sensitivity to exogenous agonists, including $N$-methyl-D-aspartate (NMDA), 2-amino3-(5-methyl-3-oxo-1,2-oxazol-4-yl) propanoic acid (AMPA), and kainic acid. This broad classification-into NMDA-, AMPA-, and kainatetype glutamate receptors-has remained useful and is now known to reflect different subunit compositions. As discussed below, glutamate receptors are found throughout the central nervous system on dendritic shafts and spines of multiple cell types and contribute to cytosolic $\mathrm{Ca}^{2+}$ elevation both directly and indirectly.

\section{NMDA-Type Glutamate Receptors}

NMDA-type glutamate receptors (NMDARs) show the highest fractional $\mathrm{Ca}^{2+}$ permeability of all glutamate receptors. Approximately 15\% of the current through NMDARs is mediated by $\mathrm{Ca}^{2+}$ influx under physiological conditions (Schneggenburger et al. 1993; Jane et al. 2009). Thus, NMDARs are the predominant source of synaptic $\mathrm{Ca}^{2+}$ signals in a variety of cells, including pyramidal neurons in both the CA1 (Müller and Connor 1991; Regehr and Tank 1992; Mainen et al. 1999; Yuste et al. 1999; Kovalchuk et al. 2000; Sobczyk et al. 2005; Bloodgood and Sabatini 2007b) and CA3 (Reid et al. 2001) regions of the hippocampus, spiny stellate (Nevian and Sakmann 2004), and pyramidal neurons of the neocortex (Koester and Sakmann 1998; Schiller et al. 1998), striatal medium spiny neurons (Carter and Sabatini 2004; Higley and Sabatini 2010), and olfactory granule cells (Egger et al. 2005). Because NMDARs are usually located on dendritic spines, their activation by glutamate produces a highly compartmentalized $\mathrm{Ca}^{2+}$ transient that is largely limited to the activated spine, and blocking NMDAR activation with pharmacological antagonists such as APV or CPP typically reduces or eliminates synaptic $\mathrm{Ca}^{2+}$ signals in spines (Sabatini et al. 2002; Sobczyk et al. 2005). This rise in $\mathrm{Ca}^{2+}$ concentration regulates diverse processes including local biochemical signaling, protein/ membrane trafficking, synaptic plasticity, and cell growth.

The number of NMDARs activated in a single spine during a synaptic event was estimated using two-photon fluorescent imaging (Nimchinsky et al. 2004). Results suggested that less than five and, in some cases, only a single receptor opens under physiological conditions. In a resting neuron, this opening produces a total $\mathrm{Ca}^{2+}$ influx of about 6000 ions into a spine head with a volume of $1 \mathrm{fL}$, corresponding to a concentration of $\sim 10 \mu \mathrm{M}$ (Sabatini et al. 2002). Of course, $90-95 \%$ of these ions are rapidly bound by various internal buffering molecules, leading to a change in free $\mathrm{Ca}^{2+}$ concentration of $\sim 1 \mu \mathrm{M}$ (Sabatini et al. 2002; Higley and Sabatini 2008).

Structurally, NMDARs are heteromeric tetramers typically consisting of two obligatory GluN1 subunits and two accessory GluN2 subunits (see Smart and Paoletti 2012). Some subunits also have multiple isoforms and, in some cases, multiple splice variants (Nakanishi et al. 1992; Sugihara et al. 1992). The structural diversity of NMDAR subunits contributes to functional heterogeneity of the channel. For example, in comparison with GluN2A-containing receptors, NMDARs with GluN2B subunits show higher affinity for glutamate binding, slower channel kinetics, and higher fractional $\mathrm{Ca}^{2+}$ permeability (Monyer et al. 1994; Vicini 1998; Sobczyk et al. 2005).

The influence of subunit composition on $\mathrm{Ca}^{2+}$ signaling suggests that activation of receptors composed of distinct subunit combinations may trigger different biological pathways. 
M.J. Higley and B.L. Sabatini

This hypothesis is supported by immunogold electron microscopy studies showing that GluN2Aand GluN2B-containing receptors may be differentially expressed across synapses (He et al. 1998). Similarly, stimulation of single postsynaptic contacts with two-photon glutamate uncaging has shown that the contributions of GluN2A- and GluN2B-containing receptors to NMDAR-dependent currents and $\mathrm{Ca}^{2+}$ transients vary widely from spine to spine (Sobczyk et al. 2005). Antagonism of GluN2B-mediated $\mathrm{Ca}^{2+}$ transients with the selective blocker ifenprodil reduces both the amplitude and interspine variability of NMDAR-mediated $\mathrm{Ca}^{2+}$ transients, consistent with heterogeneous expression of GluN2B subunits at subsets of synapses (Sobczyk et al. 2005).

Distinct subunits may also play a critical role in the plasticity of synaptic strength. In many brain areas, there is a developmental switch in synapses from GluN2B- to GluN2A-containing NMDARs that coincides with the maturation of neuronal circuits (Monyer et al. 1994; Sheng et al. 1994). Additionally, subunit composition may be rapidly regulated in response to plasticity-inducing stimuli. Thus, induction of longterm potentiation at CA 3 to CA1 synapses in the hippocampus of young rats is accompanied by a subunit switch from GluN2B to GluN2A (Bellone and Nicoll 2007). Finally, differential coupling to downstream $\mathrm{Ca}^{2+}$-dependent signaling pathways may allow GluN2A- versus GluN2Bcontaining receptors to have different functional implications for plasticity induction (Liu et al. 2004; Massey et al. 2004).

One of the most notable features of the NMDAR is that the conductance of cations, including $\mathrm{Ca}^{2+}$, is strongly regulated by membrane potential due to pore blockade by extracellular magnesium ions. Depolarization of the membrane potential by $20 \mathrm{mV}$ decreases the affinity of $\mathrm{Mg}^{2+}$ for the NMDAR by nearly 10-fold (Jahr and Stevens 1990b). This property allows NMDARs to serve as coincidence detectors, in that synaptic current and local $\mathrm{Ca}^{2+}$ influx are strongly augmented by near-simultaneous membrane depolarization and glutamate binding. Postsynaptic membrane depolarization that relieves $\mathrm{Mg}^{2+}$ block occurs following strong synaptic activation. In addition, transient depolarization occurs when action potentials propagate antidromically through the dendritic arbor, potentiating $\mathrm{Ca}^{2+}$ influx through NMDARs (Yuste and Denk 1995; Magee and Johnston 1997; Koester and Sakmann 1998; Carter and Sabatini 2004; Nevian and Sakmann 2004). This enhancement may contribute to $\mathrm{Ca}^{2+}$-dependent synaptic plasticity that is mediated by precisely timed presynaptic and postsynaptic activity (Bender et al. 2006; Nevian and Sakmann 2006). Nevertheless, even at the resting potentials of most cells, $\mathrm{Mg}^{2+}$ block is incomplete, and glutamate binding to NMDARs can evoke $\mathrm{Ca}^{2+}$ influx in the absence of additional depolarization (Jahr and Stevens 1990a; Sabatini et al. 2002).

$\mathrm{Ca}^{2+}$ influx through NMDARs is also regulated by receptor phosphorylation, providing a biochemical means to alter synaptic $\mathrm{Ca}^{2+}$ signals. Protein kinase A (PKA) regulates the $\mathrm{Ca}^{2+}$ permeability of both GluN2A- and GluN2B-containing receptors (Skeberdis et al. 2006; Higley and Sabatini 2008; Chalifoux and Carter 2010). This mechanism underlies the modulation of NMDAR $\mathrm{Ca}^{2+}$ signaling by various G-proteincoupled receptors (see Box 2). $\mathrm{Ca}^{2+}$ permeability of NMDARs is also controlled by a negativefeedback loop such that repetitive activation of GluN2B-containing receptors activates a serinethreonine phosphatase that decreases $\mathrm{Ca}^{2+}$ permeability (Sobczyk and Svoboda 2007).

\section{Non-NMDA-Type Glutamate Receptors}

AMPA-type glutamate receptors (AMPARs) are heteromeric tetramers, typically comprising dimer pairs of GluA2 and either GluA1, GluA3, or GluA4 (Greger et al. 2007; Nakagawa 2010). The presence of a GluA2 subunit renders AMPARs minimally permeable to $\mathrm{Ca}^{2+}$ ions. However, a subset of AMPARs lacking GluA2 subunits is expressed in populations of inhibitory neurons, including cortical and hippocampal interneurons (Burnashev et al. 1992; Cull-Candy et al. 2006), striatal medium spiny neurons (Carter and Sabatini 2004), and cerebellar Purkinje cells (Denk et al. 1995). $\mathrm{Ca}^{2+}$-permeable AMPARs have also been found in excitatory neurons of 


\section{BOX 2. REGULATION OF NMDA RECEPTOR-DEPENDENT Ca ${ }^{2+}$ INFLUX BY PKA}

$\mathrm{Ca}^{2+}$ influx through NMDA-type glutamate receptors (NMDARs) is an essential step in the linkage between synaptic transmission and a variety of cellular processes including synaptogenesis, longterm changes in synaptic efficacy, membrane protein trafficking, gene transcription and translation, and cell death and survival pathways (Kennedy et al. 2005). Dysregulation of NMDAR-mediated $\mathrm{Ca}^{2+}$ influx is implicated in schizophrenia and in excitotoxic cell death associated with stroke, epilepsy, head trauma, and neurodegenerative disease (Lau and Zukin 2007; Lau and Tymianski 2010). Intriguingly, several recent studies have shown that the $\mathrm{Ca}^{2+}$ permeability of NMDARs is controlled by distinct neuromodulatory systems in the brain, opening up new avenues in our understanding of this signaling pathway.

NMDARs are regulated by the activity of protein kinase A (PKA), which, along with protein phosphatase-1, is coupled to NMDARs via an A-kinase anchoring protein (AKAP) (Westphal et al. 1999). Furthermore, NMDARs are known molecular targets of PKA phosphorylation. Skeberdis et al. (2006) showed that PKA selectively augmented the permeation of $\mathrm{Ca}^{2+}$ ions through NMDARs in both cultured hippocampal neurons and acutely prepared hippocampal slices. This modulation was further seen as an enhancement of NMDAR-mediated $\mathrm{Ca}^{2+}$ transients in synaptically activated dendritic spines with no concomitant change in total synaptic current. Blocking PKA activity reduced the early phase of NMDAR-dependent long-term potentiation of hippocampal synapses, suggesting that NMDAR $\mathrm{Ca}^{2+}$ permeability is a key target for the modulation of synaptic plasticity.

Higley and Sabatini (2010) showed that the activation of type 2 dopamine receptors (D2Rs) inhibited NMDAR-mediated synaptic $\mathrm{Ca}^{2+}$ influx into the dendritic spines of striatal medium spiny neurons. D2Rs are negatively coupled to cyclic AMP generation and PKA activity via their associated $\mathrm{G}_{\alpha i}$ subunit, and the inhibition was both mimicked and occluded by blockers of PKA. Moreover, the actions of D2Rs were opposed by activating type A2 adenosine receptors (A2ARs), which are positively coupled to PKA via $G_{\alpha s}$. These results suggest a likely cellular mechanism underlying the analogous actions of D2Rs and A2ARs on NMDAR-dependent long-term plasticity of corticostriatal synapses (Shen et al. 2008). In addition, Chalifoux and Carter (2010) found that activation of $\mathrm{G}_{\alpha i}$-coupled $\mathrm{GABA}_{\mathrm{B}}$ receptors also inhibits synaptic NMDAR-mediated $\mathrm{Ca}^{2+}$ influx in pyramidal neurons of the neocortex, further indicating the generalization of this mechanism.

These studies provide strong links between the activity of PKA and the functional regulation of synaptic $\mathrm{Ca}^{2+}$ signaling. Moreover, they provide a mechanism for coupling neuromodulatory pathways to myriad cellular phenomenon such as long-term synaptic plasticity. Given the connection between NMDAR-mediated $\mathrm{Ca}^{2+}$ signals and neuropsychiatric disease, they suggest new avenues for potential therapeutic interventions.

the hippocampus (Thiagarajan et al. 2005; Plant et al. 2006) and amygdala (Clem and Huganir 2010). The presence of GluA2-lacking AMPARs is often identified by their characteristic electrophysiological signature of strong inward rectification at depolarized membrane potentials. Because of their fast kinetics, $\mathrm{Ca}^{2+}$ influx through these receptors is significantly briefer and of lower magnitude than that occurring through NMDARs. Furthermore, the functional consequences of $\mathrm{Ca}^{2+}$ influx through GluA2-lacking AMPARs is less clear, although they may contribute to synaptic plasticity in some cells (Thiagarajan et al. 2005; Plant et al. 2006; Clem and Huganir 2010).

Importantly, AMPARs indirectly contribute to $\mathrm{Ca}^{2+}$ signaling by providing membrane depolarization, relieving Mg block from NMDARs, and activating voltage-gated $\mathrm{Ca}^{2+}$ channels (see below). Similarly, kainate-type glutamate receptors are minimally permeable to $\mathrm{Ca}^{2+}$. However, they may also contribute indirectly to $\mathrm{Ca}^{2+}$ influx via membrane depolarization in some cells (Jane et al. 2009). 
M.J. Higley and B.L. Sabatini

Voltage-Gated $\mathrm{Ca}^{2+}$ Channels

Voltage-gated $\mathrm{Ca}^{2+}$ channels (VGCCs) make up a second class of contributors to $\mathrm{Ca}^{2+}$ influx. VGCCs are heteromeric complexes comprising a primary $\alpha 1$ pore-forming subunit and four additional associated subunits $(\alpha 2, \beta$, or $\gamma)$. The molecular identity of the $\alpha 1$ subunit determines the functional classification of neuronal channels as L-type $\left(\alpha 1 \mathrm{C}\right.$ and $\mathrm{D}$ or $\mathrm{Ca}_{\mathrm{V}} 1.2$ and 1.3), P/Q-type ( $\alpha 1 \mathrm{~A}$ or $\left.\mathrm{Ca}_{\mathrm{V}} 2.1\right)$, N-type $(\alpha 1 \mathrm{~B}$ or $\left.\mathrm{Ca}_{\mathrm{V}} 2.2\right)$, R-type $\left(\alpha 1 \mathrm{E}\right.$ or $\left.\mathrm{Ca}_{\mathrm{V}} 2.3\right)$, or T-type $\left(\alpha 1 \mathrm{G}, \mathrm{H}\right.$, and $\mathrm{I}$ or $\mathrm{Ca}_{\mathrm{V}} 3.1,3.2$, and 3.3) (Hille 2001).

Within dendrites and spines, VGCCs open following synaptically evoked depolarization (Miyakawa et al. 1992; Christie et al. 1995; Denk et al. 1995; Eilers et al. 1995; Magee et al. 1995; Markram et al. 1995; Finch and Augustine 1998; Schiller et al. 1998; Reid et al. 2001). Sufficient depolarization for VGCC activation can also be provided by the back-propagation of somatically generated action potentials that spread antidromically through at least the proximal portions of the dendritic arbor (Callaway and Ross 1995; Schiller et al. 1995; Yuste and Denk 1995; Svoboda et al. 1997; Helmchen et al. 1999; Koester and Sakmann 2000; Waters et al. 2003; Carter and Sabatini 2004; Nevian and Sakmann 2004; Bloodgood and Sabatini 2007b). Opening of VGCCs by action potential-evoked depolarization was used, in combination with fluctuation analysis, to estimate the number of VGCCs in a single dendritic spine at about one to 20, with the number correlating with spine volume (Sabatini and Svoboda 2000).

Numerous electrophysiological and imaging studies have revealed considerable heterogeneity in the expression of VGCC classes between different dendritic regions and across different cell types and species. In CA1 neurons of the hippocampus, $\mathrm{Ca}^{2+}$ influx into the dendritic shaft occurs via L-, R-, and T-type channels (Christie et al. 1995; Magee et al. 1995; Sabatini and Svoboda 2000), whereas influx into individual spine heads appears to be primarily limited to R- and T-type channels with a small contribution from L-type channels (Sabatini and Svoboda 2000; Yasuda et al. 2003; Hoog- land and Saggau 2004; Bloodgood and Sabatini 2007b). In cortical pyramidal neurons, dendritic VGCCs include L-, N-, P/Q-, and Rtype channels (Markram et al. 1995), whereas L-, P/Q-, and T-type channels are found in spines (Koester and Sakmann 2000). T-type VGCCs also contribute to dendritic $\mathrm{Ca}^{2+}$ signals in both olfactory granule cells (Egger et al. 2005) and cerebellar Purkinje cells (Isope and Murphy 2005). In the lateral nucleus of the amygdala, cortical and thalamic synapses are associated with spines of different sizes and voltage-gated $\mathrm{Ca}^{2+}$ channel content such that thalamic inputs are preferentially found on large spines that contain R-type channels, which may underlie differences in the amplitude of evoked $\mathrm{Ca}^{2+}$ transients and the ability to express spike-timing dependent plasticity at these two classes of synapses (Humeau et al. 2005). Within striatal medium spiny neurons, $\mathrm{Ca}^{2+}$ influx occurs primarily through $\mathrm{R}$ - and T-type channels in both dendritic shafts and spines (Higley and Sabatini 2010). Nevertheless, interpretation of many of these studies is limited by imprecise mapping between pharmacological sensitivity and VGCC $\alpha$-subunit expression, making the molecular composition of the channels mediating dendritic and spine $\mathrm{Ca}^{2+}$ influx difficult to establish conclusively. This is particular true for L-type channels (see Box 3).

\section{Internal Stores}

The contributions of $\mathrm{Ca}^{2+}$ release from internal stores to dendritic and spine $\mathrm{Ca}^{2+}$ transients following synaptic activation are more controversial and likely depend critically on the cell type under consideration as well as the experimental protocols used. Strong activation of glutamatergic inputs to hippocampal CA1 pyramidal neurons can lead to activation of group I metabotropic glutamate receptors (mGluRs), triggering a phospholipase $\mathrm{C}$ (PLC) - and inositol triphosphate (IP3)-dependent $\mathrm{Ca}^{2+}$ release from internal stores, and contributing to long-term heterosynaptic plasticity (Watanabe et al. 2006; Dudman et al. 2007; Hong and Ross 2007). This may lead to $\mathrm{Ca}^{2+}$ waves throughout large regions of the apical dendrite, regulating 


\section{BOX 3. MYSTERIES OF R- AND L-TYPE VOLTAGE-GATED $\mathrm{Ca}^{2+}$ CHANNELS- $\mathrm{Ca}^{2+}$ MICRODOMAIN ORGANIZATION OF THE SPINE}

Among the many sources of $\mathrm{Ca}^{2+}$ that are active in dendritic spines, the $\mathrm{R}$ - and L-type voltage-gated $\mathrm{Ca}^{2+}$ channels appear to have special functions that reveal an intricate subdivision of the spine into smaller $\mathrm{Ca}^{2+}$ signaling microdomains. L-type channels are often defined pharmacologically by their sensitivity to blockade by dihydropyridines such as nifedipine and nimodipine. However, neuronal L-types comprise two distinct molecular subclasses, $\mathrm{Ca}_{\vee} 1.2$ and $\mathrm{Ca}_{\vee} 1.3$, based on the identity of the pore-forming subunit, encoded by the $\alpha_{1 C}$ or $\alpha_{1 D}$ gene, respectively. One major challenge to analyzing the function of L-type channels is that $\mathrm{Ca}_{\mathrm{v}} 1.3 / \alpha_{1 D}$-encoded channels have diminished sensitivity to dihydropyridines and require substantial depolarization to display significant block by these agents (Lipscombe et al. 2004).

These properties present difficulties in detecting the activation of L-type channels during brief physiological stimuli. For example, action potential-evoked $\mathrm{Ca}^{2+}$ influx in dendritic spines of striatal medium spiny neurons has little or no sensitivity to concentrations of dihydropyridines that are selective for blockade of L-type channels. However, prolonged step depolarizations show that dihydropyridine-sensitive $\mathrm{Ca}^{2+}$ channels are, in fact, present in the spine (Higley and Sabatini 2010). A similarly perplexing result was found by the study of Yasuda et al. (2003), which described that $\mathrm{Ca}^{2+}$ influx through L-type $\mathrm{Ca}^{2+}$ channels activated a kinase cascade producing inhibition of other spine $\mathrm{Ca}^{2+}$ channels. However, no L-type-mediated $\mathrm{Ca}^{2+}$ influx could be detected in either dendrites or spines via fluorescence imaging. The resolution of this paradox is likely that the total $\mathrm{Ca}^{2+}$ influx carried by L-type channels is too small to detect but that this $\mathrm{Ca}^{2+}$ has a privileged capacity to activate downstream signaling cascades. A close apposition of Ca-sensitive proteins to the mouth of the L-type channel would allow brief and large $\mathrm{Ca}^{2+}$ accumulation within a "microdomain." Tethering of CaMKII to the carboxy-terminal domain of the $\alpha$-subunit is one such example (Hudmon et al. 2005).

Another example of $\mathrm{Ca}^{2+}$ microdomain signaling involves R-type voltage-gated channels $\left(\alpha_{1 E}\right)$ Cav2.3). These are probably the least well-characterized class of voltage-gated $\mathrm{Ca}^{2+}$ channel because of a historical lack of sensitivity to known pharmacological agents ( $R=$ resistant). However, a spider toxin (SNX-482) is available that blocks these channels with good specificity, allowing the study of their contribution to $\mathrm{Ca}^{2+}$ signaling (Newcomb et al. 1998). Early reports showed that R-type channels likely contributed the bulk of action potential-evoked $\mathrm{Ca}^{2+}$ influx in spines of hippocampal pyramidal neurons (Sabatini and Svoboda 2000; Yasuda et al. 2003). Interestingly, recent studies using SNX-482 showed that blocking $\mathrm{Ca}^{2+}$ influx through these channels increased the amplitude of synaptic potentials and, quite perplexingly, also increased the magnitude of synaptically evoked $\mathrm{Ca}^{2+}$ transients in active spines (Bloodgood and Sabatini 2007b). To explain this observation, a series of studies has now shown that $\mathrm{Ca}^{2+}$ entering through $\mathrm{R}$-type channels has a privileged ability to activate small conductance type Ca-activated potassium channels known as SK channels. SK channels open quickly during synaptic potentials and repolarize the active spine, thereby reducing the magnitude and of synaptic potentials and associated NMDA receptor-dependent $\mathrm{Ca}^{2+}$ influx (Ngo-Anh et al. 2005; Bloodgood and Sabatini 2007b). Blocking $\mathrm{Ca}^{2+}$ influx through R-type channels prevents the activation of SK channels, essentially disinhibiting synaptic signals. Interestingly, this signaling cascade is modulated by muscarinic cholinergic receptors, and the inhibition of SK channels explains much of the ability of muscarinic agents to enhance synaptic potentials, contributing to the induction of synaptic plasticity and hippocampal-dependent learning (Giessel and Sabatini 2010).

In summary, both L-type and R-type voltage-gated $\mathrm{Ca}^{2+}$ channels appear to have privileged functions in dendritic spines. That is, $\mathrm{Ca}^{2+}$ entering through these channels activates signaling cascades that are not otherwise triggered by bulk elevation in cytoplasmic $\mathrm{Ca}^{2+}$ concentration. These results are undoubtedly a manifestation of a $\mathrm{Ca}^{2+}$ microdomain organization within the spine in which specific $\mathrm{Ca}^{2+}$ sources are physically associated with $\mathrm{Ca}^{2+}$-sensitive proteins, producing important consequences for synaptic function. 
cell-wide signaling pathways. Putative IP3- and $\mathrm{Ca}^{2+}$-induced $\mathrm{Ca}^{2+}$ release from internal stores may also contribute to synaptically evoked $\mathrm{Ca}^{2+}$ transients in individual dendritic spines (Emptage et al. 1999). However, other studies have failed to find evidence for $\mathrm{Ca}^{2+}$ release from internal stores following more limited synaptic stimulation of hippocampal afferents (Mainen et al. 1999; Yuste et al. 1999; Kovalchuk et al. 2000). This disparity may be due to $\mathrm{Ca}^{2+}$ depletion of internal stores during whole-cell recordings (Hong and Ross 2007) as well as by the relatively few spines that contain endoplasmic reticulum (Holbro et al. 2009). More evidence for synaptically evoked $\mathrm{Ca}^{2+}$ release from internal stores exists for cerebellar Purkinje cells, where several groups have shown that activation of parallel fiber inputs can lead to $\mathrm{Ca}^{2+}$ release via a Group 1 mGluR-PLC-IP3-coupled pathway (Finch and Augustine 1998; Takechi et al. 1998; Miyata et al. 2000; Wang et al. 2000).

\section{MECHANISMS OF $\mathrm{Ca}^{2+}$ HANDLING AND CLEARANCE}

Following entry into the spine, free $\mathrm{Ca}^{2+}$ concentration increases and then decreases rapidly because of the action of $\mathrm{Ca}^{2+}$-binding proteins and $\mathrm{Ca}^{2+}$ extrusion mechanisms. This rapid clearance is essential to maintaining spatially and temporally localized $\mathrm{Ca}^{2+}$ signals that can mediate synapse-specific (homosynaptic) forms of plasticity as well as the induction of spike timingdependent plasticity. The timing and magnitude of synaptic $\mathrm{Ca}^{2+}$ transients in active dendritic spines are determined by an interplay between the kinetics of opening of $\mathrm{Ca}^{2+}$ sources, the on and off rates of $\mathrm{Ca}^{2+}$ binding to proteins and lipids, and the membrane densities and transport rates of $\mathrm{Ca}^{2+}$ transporters and exchangers.

\section{$\mathrm{Ca}^{2+}$-Binding Proteins}

The human genome contains more than 200 proteins with EF-hands, prototypical $\mathrm{Ca}^{2+}$ binding domains, suggesting a large family of $\mathrm{Ca}^{2+}$-binding proteins. Some of these represent direct $\mathrm{Ca}^{2+}$-activated enzymes, such as the phosphatase calcineurin or the protease calpain.
Others, such as calmodulin, are present at high levels and, upon $\mathrm{Ca}^{2+}$ binding, undergo a conformational change that promotes interaction with and activation of enzymes such as CaMKII. Notably, CaMKII also binds $\mathrm{Ca}^{2+}$ directly, leading to a synergistic activation via $\mathrm{Ca}^{2+}$ and $\mathrm{Ca}^{2+} /$ calmodulin signaling. However, a subset of $\mathrm{Ca}^{2+}$-binding proteins may simply bind $\mathrm{Ca}^{2+}$ in order to modulate the spatial and temporal profile of $\mathrm{Ca}^{2+}$ signaling. This group includes the prototypical $\mathrm{Ca}^{2+}$ buffering proteins parvalbumin, calretinin, and calbindin. These proteins are found in the dendrites and axons of many neuron classes, particularly inhibitory interneurons. However, the properties and expression patterns of $\mathrm{Ca}^{2+}$ buffering proteins vary greatly, and their functional significance is poorly understood.

The $\mathrm{Ca}^{2+}$ buffering capacity of a molecule is typically referred to as $\kappa$ and is roughly defined as the ratio of the number of $\mathrm{Ca}^{2+}$ ions that are bound to proteins to the number of $\mathrm{Ca}^{2+}$ ions that remain free (see Box 1) (Neher and Augustine 1992):

$$
\kappa=\frac{[\mathrm{Ca}]_{\text {bound }}}{[\mathrm{Ca}]_{\text {free }}}
$$

The value of $\kappa$ has profound implications for $\mathrm{Ca}^{2+}$ signaling because the amplitude of evoked $\mathrm{Ca}^{2+}$ transients is inversely proportional to $\kappa$, whereas their duration is directly proportional to $\kappa$ (Box 1). For pyramidal neurons, $\kappa$ is $100-$ 200 near the soma and base of the apical dendrite, whereas $\kappa=20$ in distal dendrites and dendritic spines. Thus, only $\sim 1 \%-5 \%$ of the $\mathrm{Ca}^{2+}$ that enters the cell remains unbound (Helmchen et al. 1996; Lee et al. 2000a; Maravall et al. 2000; Sabatini et al. 2002). The relatively low $\kappa$ of spines and dendrites allows for rapid $\mathrm{Ca}^{2+}$ signaling in which large transients are generated when a $\mathrm{Ca}^{2+}$ channel opens and are rapidly dissipated (with $\sim 15 \mathrm{msec}$ ) after closure of the channel. For these reasons, action potential and synaptically evoked $\mathrm{Ca}^{2+}$ transients are large $(\sim 1 \mu \mathrm{M})$ and closely follow the kinetics of opening of $\mathrm{Ca}^{2+}$ sources (Sabatini et al. 2002).

In contrast, $\kappa$ is significantly larger in cerebellar Purkinje cells and inhibitory interneu- 
rons that express parvalbumin (PV), a kinetically slow and high-affinity $\mathrm{Ca}^{2+}$-binding protein (Lee et al. 2000a,b; Goldberg et al. 2003; Soler-Llavina and Sabatini 2006). The peculiar properties of PV shape $\mathrm{Ca}^{2+}$ signaling in these cells. Because PV binds $\mathrm{Mg}^{2+}$ and $\mathrm{Ca}^{2+}$ competitively, $\mathrm{Ca}^{2+}$ equilibrates slowly with $\mathrm{PV}$ such that the binding reaction does not reach equilibrium for tens of milliseconds. During this "non-equilibrium" phase of $\mathrm{Ca}^{2+}$ signaling, $\mathrm{Ca}^{2+}$ remains free and at elevated levels. However, the binding of $\mathrm{Ca}^{2+}$ to PV subsequently returns $\mathrm{Ca}^{2+}$ to near resting levels, and once $\mathrm{Ca}^{2+}$ reaches equilibrium with $\mathrm{PV}$, the further decay of $\left[\mathrm{Ca}^{2+}\right]$ to resting levels occurs slowly (Collin et al. 2005; Soler-Llavina and Sabatini 2006; Muller et al. 2007). For these reasons, in PVexpressing neurons, the decay of evoked $\mathrm{Ca}^{2+}$ transients is typically complex and displays multiple time constants. In contrast, in pyramidal neurons for which $\mathrm{Ca}^{2+}$ buffers are thought to rapidly bind $\mathrm{Ca}^{2+}$, equilibrium is reached quickly and the time course of $\mathrm{Ca}^{2+}$ clearance is well described by a single exponential process corresponding to extrusion (Helmchen et al. 1996; Sabatini et al. 2002).

In addition to regulating the time course of $\mathrm{Ca}^{2+}$ clearance, $\mathrm{PV}$ may play an important role in compartmentalizing $\mathrm{Ca}^{2+}$ in neurons that lack dendritic spines (Goldberg et al. 2003; Soler-Llavina and Sabatini 2006). This has been closely examined in cerebellar stellate cells, aspiny cells that express synapse-specific and $\mathrm{Ca}^{2+}$-dependent forms of plasticity. If $\mathrm{Ca}^{2+}$ diffused rapidly away from the site of entry into the dendrite, it would be impossible to maintain the synapse specificity of $\mathrm{Ca}^{2+}$-dependent processes. In contrast, if an aspiny neuron restricted diffusion by the expression of a high concentration of fast-acting $\mathrm{Ca}^{2+}$ buffer, then the amplitude of evoked $\mathrm{Ca}^{2+}$ transients might be too small to effectively activate $\mathrm{Ca}^{2+}$-dependent processing. PV allows for large $\mathrm{Ca}^{2+}$ transients because of its slow kinetics, but because of its high affinity, effectively buffers $\mathrm{Ca}^{2+}$ after a short lag. This allows synaptic $\mathrm{Ca}^{2+}$ in smooth dendrites to induce synapse specific $\mathrm{Ca}^{2+}$-dependent forms of plasticity (Soler-Llavina and Sabatini 2006).
The function of $\mathrm{Ca}^{2+}$-binding proteins in pyramidal neurons is less clear. Because the spine head is a small volume that is separated from the dendrite by a thin neck, it naturally allows for large and compartmentalized $\mathrm{Ca}^{2+}$ transients such that $\mathrm{Ca}^{2+}$-binding proteins are not needed for this purpose. Thus, $\mathrm{Ca}^{2+}$-binding proteins may largely serve a signaling role. This is illustrated by calmodulin, which binds four $\mathrm{Ca}^{2+}$ ions and once fully occupied can bind to and activate a variety of proteins, being a major determinant of the $\mathrm{Ca}^{2+}$ buffering capacity of dendritic spines (Kakiuchi et al. 1982; Sabatini et al. 2002), at least for CA1 pyramidal neurons. On the other hand, it is difficult to draw conclusions that apply to all pyramidal neurons because there are differences in the $\mathrm{Ca}^{2+}$ buffering across these neurons that are of functional importance. For example, pyramidal neurons of the CA2 subfield of the hippocampus express more calciumbinding proteins than CA1 pyramidal neurons (Leranth and Ribak 1991; Seress et al. 1993; Lein et al. 2007), a difference the reduces the amplitude of spine $\mathrm{Ca}^{2+}$ transients (see below) ( $\mathrm{Si}-$ mons et al. 2009). The relative low amplitude of synaptic $\mathrm{Ca}^{2+}$ transients in active spines of these cells may explain the difficulty of induction of long-term potentiation in CA2 compared with in CA1 as well as their resistance to seizure-induced death (Leranth and Ribak 1991; Simons et al. 2009). It is interesting to note that the high $\kappa$ is reflected in the low amplitude of evoked transients but that a high $\mathrm{Ca}^{2+}$ extrusion rate (see below) compensates for the expected slowing of $\mathrm{Ca}^{2+}$ clearance, yielding $\mathrm{Ca}^{2+}$ transients whose kinetics do not differ significantly from those in CA1 (Simons et al. 2009).

\section{$\mathrm{Ca}^{2+}$ Extrusion}

Three main avenues exist to clear $\mathrm{Ca}^{2+}$ from the cytoplasm. First, ATP-dependent $\mathrm{Ca}^{2+}$ pumps, such as the plasmalemmal $\mathrm{Ca}^{2+}$ ATPase (PMCA), move $\mathrm{Ca}^{2+}$ across the cell membrane from the cytosol into the extracellular space. PMCA isoforms have been found both in the postsynaptic density and localized to spines, placing them appropriately to rapidly clear $\mathrm{Ca}^{2+}$ from the spine head (Garside et al. 2009; Burette et al. 
2010; Kenyon et al. 2010). The high expression of PMCA in pyramidal neurons may explain the rapid $\mathrm{Ca}^{2+}$ clearance capacity of these cells (Jensen et al. 2004; Kip et al. 2006). The efficacy of PMCA is itself regulated by intracellular $\mathrm{Ca}^{2+}$ such that at high $\mathrm{Ca}^{2+}$ concentrations, the efficiency of PMCA-dependent $\mathrm{Ca}^{2+}$ extrusion is decreased, resulting in slowed $\mathrm{Ca}^{2+}$ clearance during prolonged excitation (Scheuss et al. 2006). The mechanism of this slowing may include $\mathrm{Ca}^{2+}$-dependent activation of proteases that act on PMCA (Ferragamo et al. 2009), although this irreversible mechanism cannot account for the transient slowing of $\mathrm{Ca}^{2+}$ clearance seen following action potential trains (Scheuss et al. 2006). The proteins comprising the $\mathrm{Na}^{+} / \mathrm{Ca}^{2+}$ exchangers (NCX1-3) have also been localized to dendrites and dendritic spines with the distribution varying by isoform (Lorincz et al. 2007; Minelli et al. 2007). Functional analysis suggests that these proteins play a major functional role in clearance of spine $\mathrm{Ca}^{2+}$ (Scheuss et al. 2006).

Second, $\mathrm{Ca}^{2+}$ can be actively pumped into the lumen of intracellular organelles. The sarcoendoplasmic reticulum Ca-ATPase (SERCA) moves $\mathrm{Ca}^{2+}$ across the endoplasmic reticulum (ER) membrane and sequesters it within this organelle. The activity of SERCA may account for up to $50 \%$ of the clearance of spine $\mathrm{Ca}^{2+}$ transients during single action or synaptic potentials (Majewska et al. 2000a; Sabatini et al. 2002). This same pump serves to constitutively load ER with $\mathrm{Ca}^{2+}$, and its activity is necessary to support IP3- and $\mathrm{Ca}^{2+}$-induced $\mathrm{Ca}^{2+}$ release from intracellular stores (see "Internal Stores" above). Although mitochondria can also rapidly uptake and release $\mathrm{Ca}^{2+}$, the significance of mitochondrial $\mathrm{Ca}^{2+}$ handling to postsynaptic signaling is unclear. Pharmacological manipulation of mitochondrial $\mathrm{Ca}^{2+}$ signaling is typically accomplished by destroying the mitochondrial membrane potential and associated ATP production. Thus, it has been difficult to selectively examine the function of mitochondrial $\mathrm{Ca}^{2+}$ uptake without also perturbing the energetic state of the cell.

Third, in theory, $\mathrm{Ca}^{2+}$ can diffuse away from the site of entry. This mechanism of clearance can only be relevant in conditions in which gradients of $\mathrm{Ca}^{2+}$ exist within the cell, such as when a synapse is active and its neighbors are not. Within the spine head, $\mathrm{Ca}^{2+}$ is expected to quickly reach diffusional equilibration such that the concentration of free $\mathrm{Ca}^{2+}$ throughout the head is likely uniform within $\sim 1 \mathrm{msec}$ of closure of the $\mathrm{Ca}^{2+}$ sources. Synaptically evoked $\mathrm{Ca}^{2+}$ signals do form a gradient between the spine head and dendritic shaft, suggesting that $\mathrm{Ca}^{2+}$ might dissipate by diffusion across the spine neck (Majewska et al. 2000a,b; Noguchi et al. 2005). However, other studies suggest that when the effects of $\mathrm{Ca}^{2+}$ indicators on $\mathrm{Ca}^{2+}$ signaling are properly accounted for, free $\mathrm{Ca}^{2+}$ has a very short lifetime in the spine and does not diffuse far (Sabatini et al. 2002; Sobczyk et al. 2005). Instead, $\mathrm{Ca}^{2+}$ is quickly removed from the spine cytoplasm before it has a chance to diffuse across the neck.

\section{CONCLUSION}

In summary, synaptically evoked $\mathrm{Ca}^{2+}$ transients in dendritic spines are shaped by a complex interplay between many $\mathrm{Ca}^{2+}$ sources, pumps, and binding proteins, as well as by the biophysics of $\mathrm{Ca}^{2+}$ diffusion and spine morphology. Many classes of intracellular proteins respond to changes in postsynaptic $\mathrm{Ca}^{2+}$ to transduce electrical signaling into the regulation of enzymatic cascades. Our understanding of the factors governing $\mathrm{Ca}^{2+}$ signaling has increased dramatically, but many basic questions, such as the importance of intracellular $\mathrm{Ca}^{2+}$ stores, remain unanswered. Furthermore, as more classes of neurons are studied biophysically, it is becoming clear that neurons have highly heterogeneous $\mathrm{Ca}^{2+}$ handling mechanisms that likely have significant functional implications.

\section{REFERENCES}

* Reference is also in this collection.

Bellone C, Nicoll RA. 2007. Rapid bidirectional switching of synaptic NMDA receptors. Neuron 55: 779-785.

Bender VA, Bender KJ, Brasier DJ, Feldman DE. 2006. Two coincidence detectors for spike timing-dependent plasticity in somatosensory cortex. J Neurosci 19: 4166-4177. 
Bloodgood BL, Sabatini BL. 2007a. $\mathrm{Ca}^{2+}$ signaling in dendritic spines. Curr Opin Neurobiol 17: 345-351.

Bloodgood BL, Sabatini BL. 2007b. Nonlinear regulation of unitary synaptic signals by $\mathrm{CaV}(2.3)$ voltage-sensitive calcium channels located in dendritic spines. Neuron 53: $249-260$.

Bloodgood BL, Giessel AJ, Sabatini BL. 2009. Biphasic synaptic Ca influx arising from compartmentalized electrical signals in dendritic spines. PLoS Biol 7: e1000190.

Burette AC, Strehler EE, Weinberg RJ. 2010. A plasma membrane $\mathrm{Ca}^{2+}$ ATPase isoform at the postsynaptic density. Neuroscience 169: 987-993.

Burnashev N, Monyer H, Seeburg PH, Sakmann B. 1992. Divalent ion permeability of AMPA receptor channels is dominated by the edited form of a single subunit. $\mathrm{Neu}$ ron 8: 189-198.

Callaway JC, Ross WN. 1995. Frequency-dependent propagation of sodium action potentials in dendrites of hippocampal CA1 pyramidal neurons. J Neurophysiol 74: $1395-1403$.

Canepari M, Nelson L, Papageorgiou G, Corrie JE, Ogden D. 2001. Photochemical and pharmacological evaluation of 7-nitroindolinyl-and 4-methoxy-7-nitroindolinyl-amino acids as novel, fast caged neurotransmitters. J Neurosci Methods 112: 29-42.

Carter AG, Sabatini BL. 2004. State-dependent calcium signaling in dendritic spines of striatal medium spiny neurons. Neuron 74: 483-493.

Chalifoux JR, Carter AG. 2010. GABA $\mathrm{B}$ receptors modulate NMDA receptor calcium signals in dendritic spines. Neuron 66: $101-113$.

Christie BR, Eliot LS, Ito K, Miyakawa H, Johnston D. 1995. Different $\mathrm{Ca}^{2+}$ channels in soma and dendrites of hippocampal pyramidal neurons mediate spike-induced $\mathrm{Ca}^{2+}$ influx. J Neurophysiol 73: 2553-2557.

Clem RL, Huganir RL. 2010. Calcium-permeable AMPA receptor dynamics mediate fear memory erasure. Science 330: $1108-1112$

Collin T, Chat M, Lucas MG, Moreno H, Racay P, Schwaller B, Marty A, Llano I. 2005. Developmental changes in parvalbumin regulate presynaptic $\mathrm{Ca}^{2+}$ signaling. J Neurosci 25: 96-107.

Cox G, Sheppard CJR. 2004. Practical limits of resolution in confocal and non-linear microscopy. Microsc Res Tech 63 : $18-22$.

Cull-Candy S, Kelly L, Farrant M. 2006. Regulation of $\mathrm{Ca}^{2+}$ permeable AMPA receptors: Synaptic plasticity and beyond. Curr Opin Neurobiol 16: 288-297.

Denk W, Svoboda K. 1997. Photon upmanship: Why multiphoton imaging is more than a gimmick. Neuron 18 351-357.

Denk W, Strickler JH, Webb WW. 1990. Two-photon laser scanning fluorescence microscopy. Science 248: 73-76.

Denk W, Sugimori M, Llinás R. 1995. Two types of calcium response limited to single spines in cerebellar Purkinje cells. Proc Natl Acad Sci 92: 8279-8282.

Dudman JT, Tsay D, Siegelbaum SA. 2007. A role for synaptic inputs at distal dendrites: Instructive signals for hippocampal long-term plasticity. Neuron 56: 866-879.

Egger V, Svoboda K, Mainen ZF. 2005. Dendrodendritic synaptic signals in olfactory bulb granule cells: Local spine boost and global low-threshold spike. J Neurosci 25: $3521-3530$

Eilers J, Augustine GJ, Konnerth A. 1995. Subthreshold synaptic $\mathrm{Ca}^{2+}$ signalling in fine dendrites and spines of cerebellar Purkinje neurons. Nature 373: 155-158.

Emptage N, Bliss TV, Fine A. 1999. Single synaptic events evoke NMDA receptor-mediated release of calcium from internal stores in hippocampal dendritic spines. Neuron 22: 115-124.

Ferragamo MJ, Reinardy JL, Thayer SA. 2009. $\mathrm{Ca}^{2+}$-dependent, stimulus-specific modulation of the plasma membrane $\mathrm{Ca}^{2+}$ pump in hippocampal neurons. J Neurophysiol 101: 2563-2571.

Finch EA, Augustine GJ. 1998. Local calcium signalling by inositol-1,4,5-trisphosphate in Purkinje cell dendrites. Nature 396: 753-756.

Garside ML, Turner PR, Austen B, Strehler EE, Beesley PW, Empson RM. 2009. Molecular interactions of the plasma membrane calcium ATPase 2 at pre- and post-synaptic sites in rat cerebellum. Neuroscience 162: 383-395.

Giessel AJ, Sabatini BL. 2010. M1 muscarinic receptors boost synaptic potentials and calcium influx in dendritic spines by inhibiting postsynaptic SK channels. Neuron 68: $936-947$.

Goldberg JH, Tamas G, Aronov D, Yuste R. 2003. Calcium microdomains in aspiny dendrites. Neuron 40: 807-821.

Greger IH, Ziff EB, Penn AC. 2007. Molecular determinants of AMPA receptor subunit assembly. Trends Neurosci 30: 407-416.

Grunditz A, Holbro N, Tian L, Zuo Y, Oertner TG. 2008. Spine neck plasticity controls postsynaptic calcium signals through electrical compartmentalization. J Neurosci 28: $13457-13466$.

Harris KM, Stevens JK. 1988. Dendritic spines of rat cerebellar Purkinje cells: Serial electron microscopy with reference to their biophysical characteristics. J Neurosci 8: 4455-4469.

Harris KM, Stevens JK. 1989. Dendritic spines of CA 1 pyramidal cells in the rat hippocampus: Serial electron microscopy with reference to their biophysical characteristics. J Neurosci 9: 2982-2997.

* Harris KM, Weinberg RJ. 2012. Ultrastructure of synapses in the mammalian brain. Cold Spring Harb Perspect Biol doi: 10.1101/cshperspect.a005587.

He Y, Janssen WG, Morrison JH. 1998. Synaptic coexistence of AMPA and NMDA receptors in the rat hippocampus: A postembedding immunogold study. J Neurosci Res 54: 444-449.

Helmchen F, Imoto K, Sakmann B. 1996. $\mathrm{Ca}^{2+}$ buffering and action potential-evoked $\mathrm{Ca}^{2+}$ signaling in dendrites of pyramidal neurons. Biophys J 70: 1069-1081.

Helmchen F, Svoboda K, Denk W, Tank DW. 1999. In vivo dendritic calcium dynamics in deep-layer cortical pyramidal neurons. Nat Neurosci 2: 989-996.

Higley MJ, Sabatini BL. 2008. Calcium signaling in dendrites and spines: Practical and functional considerations. Neuron 59: 902-913.

Higley MJ, Sabatini BL. 2010. Competitive regulation of synaptic $\mathrm{Ca}^{2+}$ influx by $\mathrm{D} 2$ dopamine and $\mathrm{A} 2 \mathrm{~A}$ adenosine receptors. Nat Neurosci 13: 958-966. 
M.J. Higley and B.L. Sabatini

Hille B. 2001. Ion channels of excitable membranes, 3rd ed. Sinauer Associates, Sunderland, MA.

Holbro N, Grunditz A, Oertner TG. 2009. Differential distribution of endoplasmic reticulum controls metabotropic signaling and plasticity at hippocampal synapses. Proc Natl Acad Sci 106: 15055-15060.

Hong M, Ross WN. 2007. Priming of intracellular calcium stores in rat CAl pyramidal neurons. J Physiol (Lond) 584: $75-87$.

Hoogland TM, Saggau P. 2004. Facilitation of L-type $\mathrm{Ca}^{2+}$ channels in dendritic spines by activation of $\beta 2$ adrenergic receptors. J Neurosci 24: 8416-8427.

Hudmon A, Schulman H, Kim J, Maltez JM, Tsien RW, Pitt GS. 2005. CaMKII tethers to L-type $\mathrm{Ca}^{2+}$ channels, establishing a local and dedicated integrator of $\mathrm{Ca}^{2+}$ signals for facilitation. J Cell Biol 171: 537-547.

Humeau Y, Herry C, Kemp N, Shaban H, Fourcaudot E, Bissière S, Lüthi A. 2005. Dendritic spine heterogeneity determines afferent-specific Hebbian plasticity in the amygdala. Neuron 45: 119-131.

Isope P, Murphy TH. 2005. Low threshold calcium currents in rat cerebellar Purkinje cell dendritic spines are mediated by T-type calcium channels. J Physiol (Lond) 562: 257-269.

Jahr CE, Stevens CF. 1990a. A quantitative description of NMDA receptor-channel kinetic behavior. J Neurosci 10: $1830-1837$.

Jahr CE, Stevens CF. 1990b. Voltage dependence of NMDAactivated macroscopic conductances predicted by singlechannel kinetics. J Neurosci 10: 3178-3182.

Jane DE, Lodge D, Collingridge GL. 2009. Kainate receptors: Pharmacology, function and therapeutic potential. Neuropharmacology 56: 90-113.

Jensen TP, Buckby LE, Empson RM. 2004. Expression of plasma membrane $\mathrm{Ca}^{2+}$ ATPase family members and associated synaptic proteins in acute and cultured organotypic hippocampal slices from rat. Brain Res Dev Brain Res 152: 129-136.

Kakiuchi S, Yasuda S, Yamazaki R, Teshima Y, Kanda K, Kakiuchi R, Sobue K. 1982. Quantitative determinations of calmodulin in the supernatant and particulate fractions of mammalian tissues. J Biochem 92: 1041-1048.

Kao JP. 1994. Practical aspects of measuring $\left[\mathrm{Ca}^{2+}\right]$ with fluorescent indicators. Methods Cell Biol 40: 155-181.

Kennedy MB, Beale HC, Carlisle HJ, Washburn LR. 2005. Integration of biochemical signalling in spines. Nat Rev Neurosci 6: 423-434.

Kenyon KA, Bushong EA, Mauer AS, Strehler EE, Weinberg RJ, Burette AC. 2010. Cellular and subcellular localization of the neuron-specific plasma membrane calcium ATPase PMCAla in the rat brain. JComp Neurol 518: 3169-3183.

Kip SN, Gray NW, Burette A, Canbay A, Weinberg RJ, Strehler EE. 2006. Changes in the expression of plasma membrane calcium extrusion systems during the maturation of hippocampal neurons. Hippocampus 16: 20-34.

Koester HJ, Sakmann B. 1998. Calcium dynamics in single spines during coincident pre- and postsynaptic activity depend on relative timing of back-propagating action potentials and subthreshold excitatory postsynaptic potentials. Proc Natl Acad Sci 95: 9596-9601.
Koester HJ, Sakmann B. 2000. Calcium dynamics associated with action potentials in single nerve terminals of pyramidal cells in layer $2 / 3$ of the young rat neocortex. J Physiol 529: 625-646.

Kovalchuk Y, Eilers J, Lisman J, Konnerth A. 2000. NMDA receptor-mediated subthreshold $\mathrm{Ca}^{2+}$ signals in spines of hippocampal neurons. J Neurosci 20: 1791-1799.

Lau A, Tymianski M. 2010. Glutamate receptors, neurotoxicity and neurodegeneration. Pflugers Arch 460: 525-542.

Lau CG, Zukin RS. 2007. NMDA receptor trafficking in synaptic plasticity and neuropsychiatric disorders. Nat Rev Neurosci 8: 413-426.

Lee SH, Rosenmund C, Schwaller B, Neher E. 2000a. Differences in $\mathrm{Ca}^{2+}$ buffering properties between excitatory and inhibitory hippocampal neurons from the rat. J Physiol 525: 405-418.

Lee SH, Schwaller B, Neher E. 2000b. Kinetics of $\mathrm{Ca}^{2+}$ binding to parvalbumin in bovine chromaffin cells: Implications for $\left[\mathrm{Ca}^{2+}\right]$ transients of neuronal dendrites. J Physiol 525: 419-432.

Lein ES, Hawrylycz MJ, Ao N, Ayres M, Bensinger A, Bernard A, Boe AF, Boguski MS, Brockway KS, Byrnes EJ, et al. 2007. Genome-wide atlas of gene expression in the adult mouse brain. Nature 445: 168-176.

Leranth C, Ribak CE. 1991. Calcium-binding proteins are concentrated in the CA2 field of the monkey hippocampus: A possible key to this region's resistance to epileptic damage. Exp Brain Res 85: 129-136.

Lipscombe D, Helton TD, Xu W. 2004. L-type calcium channels: The low down. J Neurophysiol 92: 2633-2641.

Liu L, Wong TP, Pozza MF, Lingenhoehl K, Wang Y, Sheng M, Auberson YP, Wang YT. 2004. Role of NMDA Receptor subtypes in governing the direction of hippocampal synaptic plasticity. Science 304: 1021-1024.

Lorincz A, Rozsa B, Katona G, Vizi ES, Tamas G. 2007. Differential distribution of NCX1 contributes to spinedendrite compartmentalization in CA1 pyramidal cells. Proc Natl Acad Sci 104: 1033-1038.

Magee JC, Johnston D. 1997. A synaptically controlled, associative signal for Hebbian plasticity in hippocampal neurons. Science 275: 209-213.

Magee JC, Christofi G, Miyakawa H, Christie B, Lasser-Ross N, Johnston D. 1995. Subthreshold synaptic activation of voltage-gated $\mathrm{Ca}^{2+}$ channels mediates a localized $\mathrm{Ca}^{2+}$ influx into the dendrites of hippocampal pyramidal neurons. J Neurophysiol 74: 1335-1342.

Mainen ZF, Malinow R, Svoboda K. 1999. Synaptic calcium transients in single spines indicate that NMDA receptors are not saturated. Nature 399: 151-155.

Majewska A, Brown E, Ross J, Yuste R. 2000a. Mechanisms of calcium decay kinetics in hippocampal spines: Role of spine calcium pumps and calcium diffusion through the spine neck in biochemical compartmentalization. J Neurosci 20: 1722-1734.

Majewska A, Tashiro A, Yuste R. 2000b. Regulation of spine calcium dynamics by rapid spine motility. J Neurosci $\mathbf{2 0 \text { : }}$ $8262-8268$.

Mank M, Reiff DF, Heim N, Friedrich MW, Borst A, Griesbeck O. 2006. A FRET-based calcium biosensor with fast signal kinetics and high fluorescence change. Biophys $J$ 90: $1790-1796$. 
Maravall M, Mainen ZF, Sabatini BL, Svoboda K. 2000. Estimating intracellular calcium concentrations and buffering without wavelength ratioing. Biophys $J$ 78: $2655-$ 2667.

Markram H, Helm PJ, Sakmann B. 1995. Dendritic calcium transients evoked by single back-propagating action potentials in rat neocortical pyramidal neurons. J Physiol (Lond) 485: 1-20.

Massey PV, Johnson BE, Moult PR, Auberson YP, Brown MW, Molnar E, Collingridge GL, Bashir ZI. 2004. Differential roles of NR2A and NR2B-containing NMDA receptors in cortical long-term potentiation and long-term depression. J Neurosci 24: 7821-7828.

Matsuzaki M, Ellis-Davies GC, Nemoto T, Miyashita Y, Iino M, Kasai H. 2001. Dendritic spine geometry is critical for AMPA receptor expression in hippocampal CA1 pyramidal neurons. Nat Neurosci 4: 1086-1092.

Minelli A, Castaldo P, Gobbi P, Salucci S, Magi S, Amoroso S 2007. Cellular and subcellular localization of $\mathrm{Na}^{+}-\mathrm{Ca}^{2+}$ exchanger protein isoforms, NCX1, NCX2, and NCX3 in cerebral cortex and hippocampus of adult rat. Cell Calcium 41: 221-234.

Minta A, Kao JP, Tsien RY. 1989. Fluorescent indicators for cytosolic calcium based on rhodamine and fluorescein chromophores. J Biol Chem 264: 8171-8178.

Miyakawa H, Ross WN, Jaffe D, Callaway JC, Lasser-Ross N, Lisman JE, Johnston D. 1992. Synaptically activated increases in $\mathrm{Ca}^{2+}$ concentration in hippocampal CAl pyramidal cells are primarily due to voltage-gated $\mathrm{Ca}^{2+}$ channels. Neuron 9: 1163-1173.

Miyata M, Finch EA, Khiroug L, Hashimoto K, Hayasaka S, Oda SI, Inouye M, Takagishi Y, Augustine GJ, Kano M. 2000. Local calcium release in dendritic spines required for long-term synaptic depression. Neuron 28: 233-244.

Miyawaki A, Llopis J, Heim R, McCaffery JM, Adams JA, Ikura M, Tsien RY. 1997. Fluorescent indicators for $\mathrm{Ca}^{2+}$ based on green fluorescent proteins and calmodulin. Nature 388: $882-887$.

Monyer H, Burnashev N, Laurie DJ, Sakmann B, Seeburg PH. 1994. Developmental and regional expression in the rat brain and functional properties of four NMDA receptors. Neuron 12: 529-540.

Müller W, Connor JA. 1991. Dendritic spines as individual neuronal compartments for synaptic $\mathrm{Ca}^{2+}$ responses. Nature 354: 73-76.

Muller M, Felmy F, Schwaller B, Schneggenburger R. 2007. Parvalbumin is a mobile presynaptic $\mathrm{Ca}^{2+}$ buffer in the calyx of held that accelerates the decay of $\mathrm{Ca}^{2+}$ and shortterm facilitation. J Neurosci 27: 2261-2271.

Nagai T, Sawano A, Park ES, Miyawaki A. 2001. Circularly permuted green fluorescent proteins engineered to sense $\mathrm{Ca}^{2+}$. Proc Natl Acad Sci 98: 3197-3202.

Nakagawa T. 2010. The biochemistry, ultrastructure, and subunit assembly mechanism of AMPA receptors. Mol Neurobiol 42: 161-184.

Nakanishi N, Axel R, Shneider NA. 1992. Alternative splicing generates functionally distinct $N$-methyl-D-aspartate receptors. Proc Natl Acad Sci 89: 8552-8556.

Neher E. 1998. Usefulness and limitations of linear approximations to the understanding of $\mathrm{Ca}^{++}$signals. Cell Calcium 24: $345-357$.
Neher E, Augustine GJ. 1992. Calcium gradients and buffers in bovine chromaffin cells. J Physiol 450: 273-301.

Nevian T, Sakmann B. 2004. Single spine $\mathrm{Ca}^{2+}$ signals evoked by coincident EPSPs and backpropagating action potentials in spiny stellate cells of layer 4 in the juvenile rat somatosensory barrel cortex. J Neurosci 24: 1689-1699.

Nevian T, Sakmann B. 2006. Spine $\mathrm{Ca}^{2+}$ signaling in spiketiming-dependent plasticity. J Neurosci 26: 11001-11013.

Newcomb R, Szoke B, Palma A, Wang G, Chen X, Hopkins W, Cong R, Miller J, Urge L, Tarczy-Hornoch K, et al. 1998. Selective peptide antagonist of the class $\mathrm{E}$ calcium channel from the venom of the tarantula Hysterocrates gigas. Biochemistry 37: 15353-15362.

Ngo-Anh TJ, Bloodgood BL, Lin M, Sabatini BL, Maylie J, Adelman JP. 2005. SK channels and NMDA receptors form a $\mathrm{Ca}^{2+}$-mediated feedback loop in dendritic spines. Nat Neurosci 8: 642-649.

Nimchinsky EA, Yasuda R, Oertner TG, Svoboda K. 2004. The number of glutamate receptors opened by synaptic stimulation in single hippocampal spines. J Neurosci 24: 2054-2064.

Noguchi J, Matsuzaki M, Ellis-Davies GC, Kasai H. 2005. Spine-neck geometry determines NMDA receptor-dependent $\mathrm{Ca}^{2+}$ signaling in dendrites. Neuron 46: 609622.

Oertner TG, Sabatini BL, Nimchinsky EA, Svoboda K. 2002. Facilitation at single synapses probed with optical quantal analysis. Nat Neurosci 5: 657-664.

Plant K, Pelkey KA, Bortolotto ZA, Morita D, Terashima A, McBain CJ, Collingridge GL, Isaac JT. 2006. Transient incorporation of native GluR2-lacking AMPA receptors during hippocampal long-term potentiation. Nat Neurosci 9: 602-604.

Regehr WG, Tank DW. 1992. Calcium concentration dynamics produced by synaptic activation of CA1 hippocampal pyramidal cells. J Neurosci 12: 4202-4223.

Reid CA, Fabian-Fine R, Fine A. 2001. Postsynaptic calcium transients evoked by activation of individual hippocampal mossy fiber synapses. J Neurosci 21: 2206-2214.

Sabatini BL, Svoboda K. 2000. Analysis of calcium channels in single spines using optical fluctuation analysis. Nature 408: 589-593.

Sabatini BL, Maravall M, Svoboda K. 2001. $\mathrm{Ca}^{2+}$ signaling in dendritic spines. Curr Opin Neurobiol 11: 349-356.

Sabatini BL, Oertner TG, Svoboda K. 2002. The life cycle of $\mathrm{Ca}^{2+}$ ions in dendritic spines. Neuron 33: 439-452.

Scheuss V, Yasuda R, Sobczyk A, Svoboda K. 2006. Nonlinear $\left[\mathrm{Ca}^{2+}\right]$ signaling in dendrites and spines caused by activity-dependent depression of $\mathrm{Ca}^{2+}$ extrusion. J Neurosci 26: 8183-8194.

Schiller J, Helmchen F, Sakmann B. 1995. Spatial profile of dendritic calcium transients evoked by action potentials in rat neocortical pyramidal neurones. J Physiol (Lond) 487: $583-600$.

Schiller J, Schiller Y, Clapham DE. 1998. NMDA receptors amplify calcium influx into dendritic spines during associative pre- and postsynaptic activation. Nat Neurosci 1: $114-118$.

Schmidt H, Arendt O, Brown EB, Schwaller B, Eilers J. 2007. Parvalbumin is freely mobile in axons, somata and nuclei 
M.J. Higley and B.L. Sabatini

of cerebellar Purkinje neurones. J Neurochem 100: 727 735.

Schneggenburger R, Zhou Z, Konnerth A, Neher E. 1993. Fractional contribution of calcium to the cation current through glutamate receptor channels. Neuron 11: 133143.

Seress L, Gulyás AI, Ferrer I, Tunon T, Soriano E, Freund TF. 1993. Distribution, morphological features, and synaptic connections of parvalbumin- and calbindin D28k-immunoreactive neurons in the human hippocampal formation. J Comp Neurol 337: 208-230.

Shen W, Flajolet M, Greengard P, Surmeier DJ. 2008. Dichotomous dopaminergic control of striatal synaptic plasticity. Science 321: 848-851.

Sheng M, Cummings J, Roldan LA, Jan YN, Jan LY. 1994. Changing subunit composition of heteromeric NMDA receptors during development of rat cortex. Nature 368: $144-147$.

Simons SB, Escobedo Y, Yasuda R, Dudek SM. 2009. Regional differences in hippocampal calcium handling provide a cellular mechanism for limiting plasticity. Proc Nat Acad Sci 106: $14080-14084$

Skeberdis VA, Chevaleyre V, Lau CG, Goldberg JH, Pettit DL, Suadicani SO, Lin Y, Bennett MV, Yuste R, Castillo PE, et al. 2006. Protein kinase A regulates calcium permeability of NMDA receptors. Nature Neurosci 9: 501-510.

* Smart TG, Paoletti P. 2012. Synaptic neurotransmitter-gated receptors. Cold Spring Harb Perspect Biol doi: 10.1101/ cshperspect.a009662.

Sobczyk A, Svoboda K. 2007. Activity-dependent plasticity of the NMDA-receptor fractional $\mathrm{Ca}^{2+}$ current. Neuron 53: $17-24$

Sobczyk A, Scheuss V, Svoboda K. 2005. NMDA receptor subunit-dependent $\left[\mathrm{Ca}^{2+}\right]$ signaling in individual hippocampal dendritic spines. J Neurosci 25: 6037-6046.

Soler-Llavina GJ, Sabatini BL. 2006. Synapse-specific plasticity and compartmentalized signaling in cerebellar stellate cells. Nat Neurosci 9: 798-806.

* Südhof TC, Rizo J. 2011. Synaptic vesicle exocytosis. Cold Spring Harb Perspect Biol doi: 10.1101/a005637.cshperspect.

Sugihara H, Moriyoshi K, Ishii T, Masu M, Nakanishi S. 1992. Structures and properties of seven isoforms of the NMDA receptor generated by alternative splicing. Biochem Biophys Res Commun 185: 826-832.

Svoboda K, Denk W, Knox WH, Tsuda S. 1996. Two-photon-excitation scanning microscopy of living neurons with a saturable Bragg reflector mode-locked diodepumped Cr:LiSrAlFl laser. Opt Lett 21: 1411-1413.

Svoboda K, Denk W, Kleinfeld D, Tank DW. 1997. In vivo dendritic calcium dynamics in neocortical pyramidal neurons. Nature 385: 161-165.

Takechi H, Eilers J, Konnerth A. 1998. A new class of synaptic response involving calcium release in dendritic spines. Nature 396: 757-760.
Tank DW, Regehr WG, Delaney KR. 1995. A quantitative analysis of presynaptic calcium dynamics that contribute to short-term enhancement. J Neurosci 15: 7940-7952.

Thiagarajan TC, Lindskog M, Tsien RW. 2005. Adaptation to synaptic inactivity in hippocampal neurons. Neuron 47: 725-737.

Tian L, Hires SA, Mao T, Huber D, Chiappe ME, Chalasani SH, Petreanu L, Akerboom J, McKinney SA, Schreiter ER, et al. 2009. Imaging neural activity in worms, flies and mice with improved GCaMP calcium indicators. Nat Methods 6: 875-881.

Tsien RY. 1980. New calcium indicators and buffers with high selectivity against magnesium and protons: Design, synthesis, and properties of prototype structures. Biochemistry 19: 2396-2404.

Vicini S. 1998. Functional and pharmacological differences between recombinant $N$-methyl-D-aspartate receptors. J Neurophysiol 79: 555-566.

Wang SS, Denk W, Häusser M. 2000. Coincidence detection in single dendritic spines mediated by calcium release. Nat Neurosci 3: 1266-1273.

Watanabe S, Hong M, Lasser-Ross N, Ross WN. 2006. Modulation of calcium wave propagation in the dendrites and to the soma of rat hippocampal pyramidal neurons. J Physiol (Lond) 3: 455-468.

Waters J, Larkum M, Sakmann B, Helmchen F. 2003. Supralinear $\mathrm{Ca}^{2+}$ influx into dendritic tufts of layer $2 / 3$ neocortical pyramidal neurons in vitro and in vivo. J Neurosci 23: 8558-8567.

Westphal RS, Tavalin SJ, Lin JW, Alto NM, Fraser ID, Langeberg LK, Sheng M, Scott JD. 1999. Regulation of NMDA receptors by an associated phosphatase-kinase signaling complex. Science 285: 93-96.

Wokosin DL, Loughrey CM, Smith GL. 2004. Characterization of a range of fura dyes with two-photon excitation. Biophysical J 86: 1726-1738.

Yasuda R, Sabatini BL, Svoboda K. 2003. Plasticity of calcium channels in dendritic spines. Nat Neurosci 6: 948955.

Yasuda R, Nimchinsky EA, Scheuss V, Pologruto TA, Oertner TG, Sabatini BL, Svoboda K. 2004. Imaging calcium concentration dynamics in small neuronal compartments. Sci STKE 2004: p15.

Yuste R, Denk W. 1995. Dendritic spines as basic functional units of neuronal integration. Nature 375: 682-684.

Yuste R, Majewska A, Cash SS, Denk W. 1999. Mechanisms of calcium influx into hippocampal spines: Heterogeneity among spines, coincidence detection by NMDA receptors, and optical quantal analysis. J Neurosci 19: 1976-1987.

Zhou Z, Neher E. 1993. Mobile and immobile calcium buffers in bovine adrenal chromaffin cells. J Physiol 469: 245-273. 


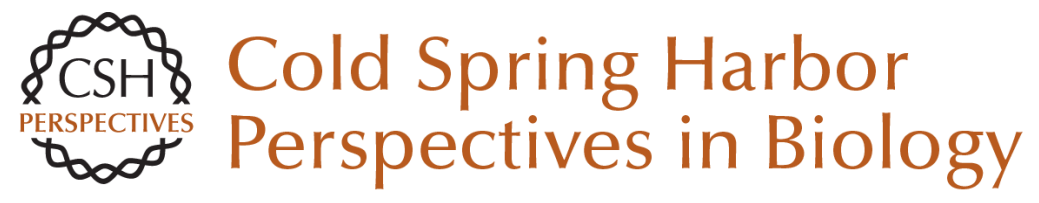

\section{Calcium Signaling in Dendritic Spines}

Michael J. Higley and Bernardo L. Sabatini

Cold Spring Harb Perspect Biol 2012; doi: 10.1101/cshperspect.a005686 originally published online February 15, 2012

\section{Subject Collection The Synapse}

Studying Signal Transduction in Single Dendritic Spines Ryohei Yasuda

Synaptic Vesicle Pools and Dynamics AbdulRasheed A. Alabi and Richard W. Tsien

Synapses and Memory Storage Mark Mayford, Steven A. Siegelbaum and Eric $R$. Kandel

Synapses and Alzheimer's Disease Morgan Sheng, Bernardo L. Sabatini and Thomas C. Südhof

Synaptic Cell Adhesion

Markus Missler, Thomas C. Südhof and Thomas Biederer

Synaptic Dysfunction in Neurodevelopmental Disorders Associated with Autism and Intellectual Disabilities

Huda Y. Zoghbi and Mark F. Bear

The Postsynaptic Organization of Synapses Morgan Sheng and Eunjoon Kim

Presynaptic LTP and LTD of Excitatory and Inhibitory Synapses

Pablo E. Castillo
Synaptic Vesicle Endocytosis

Yasunori Saheki and Pietro De Camilli

Short-Term Presynaptic Plasticity Wade G. Regehr

NMDA Receptor-Dependent Long-Term

Potentiation and Long-Term Depression

(LTP/LTD) Christian Lüscher and Robert C. Malenka

Ultrastructure of Synapses in the Mammalian

Brain Kristen M. Harris and Richard J. Weinberg

Calcium Signaling in Dendritic Spines Michael J. Higley and Bernardo L. Sabatini

Synaptic Neurotransmitter-Gated Receptors Trevor G. Smart and Pierre Paoletti

Synaptic Vesicle Exocytosis

Thomas C. Südhof and Josep Rizo

Vesicular and Plasma Membrane Transporters for Neurotransmitters

Randy D. Blakely and Robert H. Edwards

For additional articles in this collection, see http://cshperspectives.cshlp.org/cgi/collection/

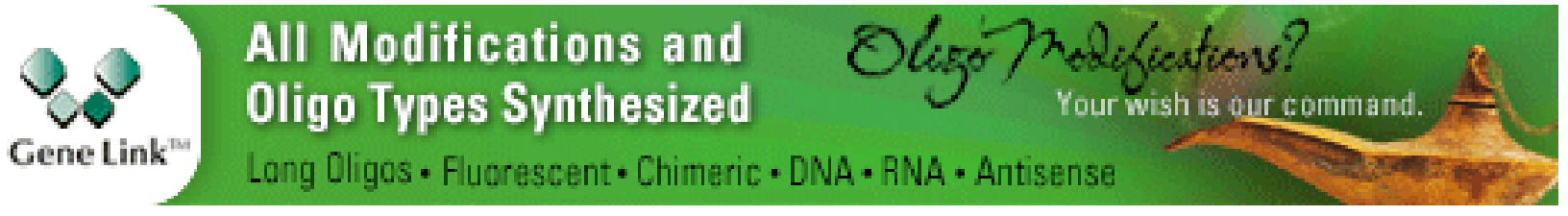

